\title{
Analysis of main risk factors contributing to obesity in the region of East Africa: meta-analysis
}

\author{
Lenka Mařincová, Simona Šafaříková, Radka Cahlíková
}

Palacky University Olomouc, Faculty of Science, Department of Development and Environmental Studies, Czech Republic.

\section{Other authors:}

Simona Šafaříková - simona.safarikova@upol.cz; Radka Cahlíková - radka.cahlikova@gmail.com

\begin{abstract}
Background: Over a few decades obesity has become a major global health problem. Its prevalence worldwide has more than doubled since 1980. The situation is expected to worsen in the future, especially in the developing countries that experience nutrition transition due to economic growth. It contributes to reduction in malnutrition which supports an increase in obesity prevalence.
\end{abstract}

Objectives: The aim of this study was to analyse the predictors of obesity in the region of East Africa.

Methods: Meta-analysis of existing studies was used in order to find the different risk factors and their significance in obesity development. Data extracted from 16 published academic research articles described the situation in East African countries. The significance of the effect of each variable was tested by means of an asymptotic chi-square test, or Fisher's exact (factorial) test and the risk ratios were calculated.

Results: Based on the chi-square test and the risk ratios of the aggregated data, three risk factors were found to be significant in the development of obesity - gender, type of residence and socio-economic status. In East African countries, women are significantly more likely to be obese. Living in an urban area and socioeconomic status are also positively associated with obesity. Because of insufficient data three other risk factors did not prove to be of any significance - alcohol consumption, smoking and education level.

Conclusion: Conclusions of this meta-analysis confirm world trends but we also found results that are not in line with them (e.g. education). This meta-analysis confirms the huge existing research gap concerning obesity predictors in the East African region.

Keywords: Obesity, meta-analysis, East Africa.

DOI: https://dx.doi.org/10.4314/ahs.v20i1.30

Cite as: Marincová L, Šafařková S, Cablikeová R. Analysis of main risk factors contributing to obesity in the region of East Africa: meta-analysis. Afri Health Sci. 2020;20(1):248-56.https:// dx.doi.org/10.4314/abs.v20i1.30

\section{Introduction}

Over a few decades obesity has become a major global health problem ${ }^{1}$. According to the World Health Organi-
Corresponding author:
Lenka Mařincová,
Department of Development
and Environmental Studies,
17. listopadu 12, 77146 Olomouc,
Czech Republic
Telephone: +420734355359
Emails: lenka.marincova@gmail.com;
lenka.marincova@upol.cz

zation (WHO) the prevalence of obesity worldwide has more than doubled since 1980 and the increase is accelerating ${ }^{2}$. The latest data from 2014 shows that more than 1.9 billion adults were overweight and of these, over 600 million were obese ${ }^{3}$. However, there are huge disparities among different geographic regions, pieces of research covering those areas and attitudes and prevention strategies against obesity. To discuss the worldwide trends of obesity, we use the WHO definition ${ }^{3}$ describing "obesity and overweight as an abnormal or excessive fat accumulation that presents a risk to health". Body Mass Index (BMI) is used as reference standard to measure $i^{4}$. According to the $\mathrm{WHO}^{3}$, overweight starts with a $\mathrm{BMI}$ equal to or more than 25 and an adult with a BMI of 30 or higher is considered obese. 
Numerous studies have recommended ${ }^{1,5-7}$ an urgent global action plan to create appropriate policies and raise public awareness about obesity. However, the main key to eliminating obesity is in prevention strategies because obesity is preventable through changes in behaviour ${ }^{5}$. The main risk factors of obesity are divided into two groups - modifiable and non-modifiable. The main focus of the prevention strategies should be on modifiable risk factors (e.g. dietary intake, physical activity, smoking, area of residence) because these are under the control ofthe affected population. No national success stories of obesity elimination have been reported in the past 33 years. According to Kelly et al. ${ }^{9}$ the population of developed countries is more prone to being obese or overweight than that of developing countries, yet it is in the latter where vast number of people are affected by this health problem $^{1,10}$ and the situation is expected to worsen in the future $^{11-13}$. Nowadays, developing countries experience nutrition transition as economic growth has changed peoples' nutritional habits $^{14}$. This contributes to reduction in malnutrition, which supports an increase in obesity prevalence $^{14}$. To date, too little research has been done on obesity and its risk factors in developing world ${ }^{14}$. During the Nairobi conference in 2009 it was stated that African continent is in urgent need to develop appropriate health policies against obesity ${ }^{15}$. These should be based on robust research and use local approaches and traditions ${ }^{16}$.

While there has been a plethora of articles about obesity published worldwide $2,5,9,10,12,14,17-19$ and partly covering the region of Africa, for the East African sub-region any overview study has not been published yet. As the African continent is very huge it is important to focus on smaller geographical parts as they have different level of development and the predictors might play diverse roles in the prevalence of obesity.

Therefore, the main aim of the presented meta-analysis is to focus on this developing region and to analyse the risk factors of obesity prevalence in order to use the results in further micro-level studies. Thereby the authors decided to use meta-analysis and to base this research on already existing articles and their aggregated data.

\section{Methods}

\section{Setting of the study}

This study defines East Africa as the East African Com- munity (EAC). This regional organization unites the republics of Burundi, Kenya, Rwanda, South Sudan, Uganda and Tanzania that belong to the category of low human development according to the Human Development Index (HDI) ${ }^{20}$.

\section{Search and inclusion criteria}

The authors decided to use meta-analysis to cover the research gap existing in the selected region. This method was employed because during the preliminary search of documents related to the obesity in East Africa, any similar research or complex studies focusing on the trends and risk factors of obesity were not identified.

Initially the search for articles in the databases (PubMed, Medline, EBSCO) started with the following keywords, separately - obesity, BMI, overweight. Each of these three keywords was combined with "East Africa" and with each country using Boolean operators (AND). All articles published until 2014 were included into the search engine. The preliminary search discovered a vast number of research articles - 1,118 in EBSCO, 1,290 in PubMed and 16,665 in Medline (altogether 19,073). Therefore, the research team decided to narrow down the search to the level of abstracts. After this step 1,303 pertinent articles were found. At this stage duplicates were removed and titles were screened independently. 254 studies were found as appropriate. Reading all the selected abstracts was the next step. After reading them, 64 academic articles were found appropriate. The condition for inclusion of the article into this study was defined in a way that obesity had to be considered as a dependent variable explained by a number of independent variables. Full texts of these articles were read and they were screened according to STROBE statement checklist. The condition for inclusion of the article into this study was defined in a way that obesity had to be considered as a dependent variable explained by a number of independent variables. 47 studies were excluded from the analysis due to insufficient information, lacking quality or inappropriate position on obesity in the research design. Finally, 20 studies could have been included in the meta-analysis but only 16 studies contained appropriate aggregated data for extraction (see Figure 1). 


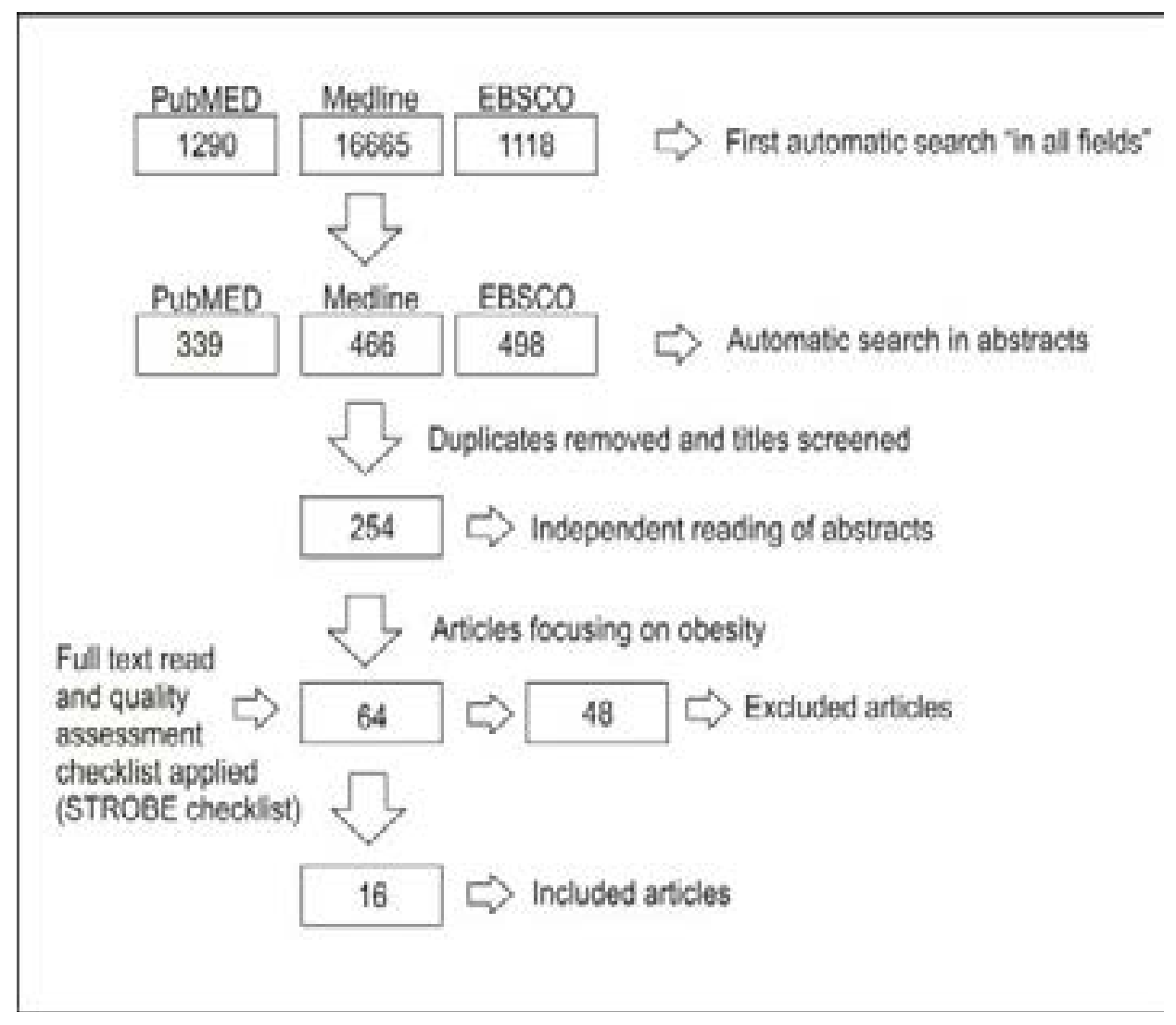

Figure 1: Articles selection process for inclusion into meta-analysis

All the authors of the selected studies were contacted by email and asked for other articles and further recommendations for the research. We received 11 replies after three rounds of email conversation. This further research did not contribute to the inclusion of any new article. The authors could work only with the aggregated data from these 16 studies as the original raw data the primary authors worked with were not accessible. Aggregated data from each study were extracted and placed in separate tables and used for the meta-analysis.

\section{Studies included in the meta-analysis}

Out of the 16 selected studies, 5 covered obesity issues in Tanzania ${ }^{21-25}, 4$ considered Uganda ${ }^{26-29}$ and 7 described Kenya $^{18,30-35}$ (see Table 2). These studies and their aggregated data served as starting point in the meta-analysis. No appropriate quality studies (based on STROBE statement) that covered Rwanda, South Sudan or Burundi were found. This confirms the existing research gap in East Africa.

All the studies selected for the meta-analysis focused on obesity as a dependent variable and used several different modifiable and non-modifiable risk factors to explain its prevalence (e.g. gender, age, level of education, socio- economic status, physical activity, area of residence, alcohol use, smoking, dietary intake, household size, marital status, occupation). All the articles used cross-sectional study design and analysed the prevalence of obesity in defined populations. Some independent variables were repeated several times and overlapped in the selected articles. These were used in the presented meta-analysis. The samples in the 16 selected articles reached from 20,035 to 532,533 participants and covered age groups ranging from 3 to 68 years. Females and males were represented. The studies used different types of random sampling (cluster, multistage, stratified), with one exception - study Ojiambo et $\mathrm{al}^{35}$ used convenience sampling. Different methods of data collection were applied - secondary data from national surveys, questionnaires, accelerometry, ultrasonography and anthropometric measurements.

\section{Statistical analysis}

Based on the availability of the data in the chosen articles several predictors were selected. Then their particular influence on obesity was studied separately. The predictors used are gender, education, type of residence, alcohol consumption, smoking and socioeconomic status. From each article the summary data were tabulated in sever- 
al separate contingency tables. The significance of the effect was tested by means of an asymptotic chi-square test, or Fisher's exact (factorial) test in the case of a low number of subjects. These tests were applied 35 times. Then, for each predictor the available data from the articles were finally pooled together in a single contingency table and the effect of the predictor was tested by the methods described above. The level of significance was set to 0.05 . The calculation of risk ratios was the second

Table 1: Pooled data of the selected indicators. steps in the meta-analysis. It was calculated for each study separately and later on for each variable together. The level of significance was set to 0.05 . All the statistical analyses were performed using the open platform VassarStats and STATA.

\section{Results}

All the predictors studied, their definitions and analyses are described hereafter. Table 1 summarizes the final contingency table results for each predictor.

\begin{tabular}{|c|c|c|c|c|c|c|c|c|c|c|c|c|}
\hline \multirow[t]{2}{*}{$\begin{array}{c}\text { Pooled data } \\
\text { (number of } \\
\text { studies included): }\end{array}$} & \multicolumn{2}{|c|}{ Gender (14) } & \multicolumn{2}{|c|}{ Education (2) } & \multicolumn{2}{|c|}{$\begin{array}{c}\text { Type of } \\
\text { residence (9) }\end{array}$} & \multicolumn{2}{|c|}{$\begin{array}{c}\text { Use of } \\
\text { alcohol (2) }\end{array}$} & \multicolumn{2}{|c|}{ Smoking (2) } & \multicolumn{2}{|c|}{$\begin{array}{c}\text { Socioeconom } \\
\text { ic status (6) }\end{array}$} \\
\hline & Female & Male & $\begin{array}{c}\text { No } \\
\text { education }\end{array}$ & Education & Rural & Urban & Yes & No & Yes & No & Poor & Rich \\
\hline Overweight/obese & 2,402 & 985 & 79 & 630 & 1,176 & 1,192 & 62 & 265 & 9 & 338 & 468 & $\begin{array}{c}1,61 \\
1\end{array}$ \\
\hline $\begin{array}{l}\text { Not } \\
\text { overweight/obese }\end{array}$ & 8,150 & 8,408 & 386 & 2,574 & 5,522 & 1,936 & 258 & 1,347 & 110 & 1,879 & 2,636 & $\begin{array}{c}3,73 \\
9\end{array}$ \\
\hline Sample size & \multicolumn{2}{|c|}{19,945} & \multicolumn{2}{|c|}{3,669} & \multicolumn{2}{|c|}{9,826} & \multicolumn{2}{|c|}{1,932} & \multicolumn{2}{|c|}{2,336} & \multicolumn{2}{|c|}{8,454} \\
\hline Chi-square test & \multicolumn{2}{|c|}{$\mathrm{p}<0.0001$} & \multicolumn{2}{|c|}{$\mathrm{p}=0.536$} & \multicolumn{2}{|c|}{$\mathrm{p}<0.0001$} & \multicolumn{2}{|c|}{$\mathrm{p}=0.331$} & \multicolumn{2}{|c|}{$\mathrm{p}=0.663$} & \multicolumn{2}{|c|}{$\mathrm{p}<0.0001$} \\
\hline $\begin{array}{l}\text { Confidence } \\
\text { interval }\end{array}$ & \multicolumn{2}{|c|}{$(1.804,2.064)$} & \multicolumn{2}{|c|}{$(0.758,1.155)$} & \multicolumn{2}{|c|}{$(0.424,0.483)$} & \multicolumn{2}{|c|}{$(0.882,1.453)$} & \multicolumn{2}{|c|}{$(0.475,1.607)$} & \multicolumn{2}{|c|}{$(0.452,0.549)$} \\
\hline
\end{tabular}

To evaluate the influence of gender in obesity, data from 14 studies $^{21-28,30-33,35,36}$ were extracted and pooled. After calculation the risk ratio the pooled data $(\mathrm{N}=19,945)$ show that women are significantly more likely to be obese than men $(p<0.0001 ; C I=(1,804 ; 2,064))$. However, in four studies ${ }^{21,31,35,36}$ the effect of gender did not reach the significance level. All these four studies focused on children and adolescents. This makes sense because it takes some time for obesity to develop, thus it is more probable to find the effect in adult populations.

Data concerning the effect of education were pooled from two articles ${ }^{25,29}$. On the individual level of both articles, education proved to be significant as a predictor of obesity, however the effects were the opposite. In Shayo et $\mathrm{al}^{25}$, having no education was associated with a significantly $(\mathrm{N}=1,249, \mathrm{p}=0.03)$ higher risk of obesity, whereas in Turi et $\mathrm{al}^{29}$ the effect was the opposite but also significant $(\mathrm{N}=2420$ - only the adult population, $\mathrm{p}=0.003)$. After pooling the data from both articles $(\mathrm{N}=3,669)$ and calculating the risk ratio, the significance of this predictor disappeared $(p=0.536 ; C I=(0,758 ; 1,155))$. Shayo et $\mathrm{al}^{25}$ focused on the adult population of both genders, whereas Turi et al. ${ }^{29}$ only carried out research into women and their children. It is not possible to conclude anything about the influence of education on obesity as we did not have enough appropriate data and both studies showed opposite results.
To test the effect of type of residence on obesity, data from 9 articles were extracted $21,23,26,27,29-31,34,35$. Type of residence was used as dichotomic variable - rural and urban. Only in one study ${ }^{26}$ did type of residence prove not to be significant. In this case, the population studied was younger adults (18-30 years). In all the other individual studies, type of residence was found to be significant, showing that people living in urban areas were more likely to be obese/overweight than those living in rural areas. When all the data were pooled $(\mathrm{N}=9,826)$ and risk ratio calculated, type of residence also proved to be highly significant $(p<0.0001 ; C I=(0,424 ; 0,483))$ with the same association as on the individual levels.

Data relating to alcohol consumption were extracted only from 2 articles ${ }^{25,26}$. This variable was dichotomic in both cases (yes/no). Based on the asymptotic chi-square test, alcohol consumption was not found to be a significant predictor of obesity in either of the studies $(p=0.23$; $\mathrm{p}=0.74)$. Then the risk ratio calculation was also applied to the pooled data, $(\mathrm{N}=1,932)$ and the same result was confirmed $(\mathrm{p}=0.331 ; \mathrm{CI}=(0,882 ; 1,453))$. It is not possible to make further conclusion about alcohol consumption as a risk factor for obesity because only two studies could provide the data.

Concerning smoking, relevant data were extracted from two studies ${ }^{26,27}$. Smoking had two different values - yes African Health Sciences Vol 20 Issue 1, March, 2020 
(people smoke) and no (people do not smoke). In the first case $^{26}$, smoking was not found to be a significant predictor of obesity $(p=0.16)$. In the second study ${ }^{27}$ smoking was shown to be a significant protective factor against obesity. When all the data were pooled $(\mathrm{N}=2,336)$ and risk ratio computed, smoking was not found to be significant $(p=0.663 C I=(0,475 ; 1,607))$. Any further conclusion cannot be made because only two studies were included.

Socio-economic status was studied based on $6 \mathrm{pa}-$ pers $^{25-27,29,31,34}$. The effect was assessed by means of the chi-square test. Based on the categorization process during the preparation of the data from each article this variable was also set into a binary system - rich/poor. In half of the studies ${ }^{25,27,29}$, socio-economic status was found to be significant for obesity meaning that rich people are more likely to be obese. Conversely, data in other 3 studies $^{26,31,34}$ did not show significance. When we pooled all the data $(\mathrm{N}=8,454)$ and counted the risk ratio, socioeconomic status was found to be significant $(\mathrm{p}=0.0001$; $\mathrm{CI}=(0,452 ; 0,549))$, saying that the status "rich" was associated with a significantly higher risk of obesity.

Table 2: List of articles included into the meta-analysis ( $\mathrm{G}$ - gender; $\mathrm{E}$ - education, $\mathrm{R}$ - type of residence; $\mathrm{A}$ - use of alcohol, $\mathrm{S}$ - smoking, $\mathrm{SE}$ socioeconomic status)

\begin{tabular}{|c|c|c|c|c|c|c|c|c|c|c|c|}
\hline $\begin{array}{c}\text { Authors } \\
\text { Date of } \\
\text { publication }\end{array}$ & Aim of the study & Study design & Sample size & Name of place & $\begin{array}{l}\text { Target population } \\
\text { Age range }\end{array}$ & \multicolumn{6}{|c|}{ Predictors extracted } \\
\hline Kenya & & & & & & G & $\mathrm{E}$ & $\mathrm{R}$ & A & $\mathrm{s}$ & SE \\
\hline $\begin{array}{l}\text { Jayne et } \\
\text { al. (2011) }\end{array}$ & $\begin{array}{l}\text { characterize the nutritional status and } \\
\text { identifysocioeconomic factors and dietary } \\
\text { habits }\end{array}$ & cross-sectional & 500 & Rural: Kisumu, Kenya Kombewa division & Adults $18-55$ & $\mathrm{x}$ & & & & & \\
\hline Gewa (2010) & $\begin{array}{l}\text { report on the prevalence of overweight and } \\
\text { obesity among children } \\
\text { examine the associations between childhood } \\
\text { overweight and maternal and child - related } \\
\text { factors }\end{array}$ & $\begin{array}{l}\text { cross-sectional } \\
\text { cluster }\end{array}$ & 1,443 & Rural and urban areas of Kenya. & Children 3-5 & $\mathrm{x}$ & & $\mathrm{x}$ & & & $\mathrm{x}$ \\
\hline $\begin{array}{l}\text { Christensen et } \\
\text { al. } \\
\text { (2008) }\end{array}$ & $\begin{array}{l}\text { assess the prevalence of obesity and differences } \\
\text { in body composition with }\end{array}$ & cross-sectional & $\begin{array}{l}1,430(53 \% \\
\text { females) }\end{array}$ & Rural and urban areas of Kenya. & Adults 17-68 & $\mathrm{x}$ & & $\mathrm{x}$ & & & \\
\hline $\begin{array}{l}\text { Kamau et } \\
\text { al. (2011) }\end{array}$ & $\begin{array}{l}\text { determine the prevalence of overweight and } \\
\text { obesity among primary school children }\end{array}$ & cross-sectional & $\begin{array}{l}5,325(2,620 \\
\text { males and } \\
2,705 \\
\text { females })\end{array}$ & Urban & Children $10-15$ & $\mathrm{x}$ & & & & & \\
\hline $\begin{array}{l}\text { Kyallo et } \\
\text { al. (2013) }\end{array}$ & $\begin{array}{l}\text { determine the prevalence of overweight and } \\
\text { obesity among children }\end{array}$ & cross-sectional & 321 & Urban (Nairobi) & $\begin{array}{l}\text { Children } \\
9-14\end{array}$ & $\mathrm{x}$ & & & & & \\
\hline $\begin{array}{l}\text { Steyn et } \\
\text { al. (2011) }\end{array}$ & $\begin{array}{l}\text { determine the nutritional status of women } \\
\text { assess the relationship of diet, demographic and } \\
\text { socioeconomic factors on their weight status }\end{array}$ & cross-sectional & 1,006 & $\begin{array}{l}\text { Rural and urban areas of Kenya (Meru, } \\
\text { Kisumu, Nakuru, and Nairobi) }\end{array}$ & $\begin{array}{l}\text { Women } \\
15-60\end{array}$ & & & $\mathrm{x}$ & & & $\mathrm{x}$ \\
\hline $\begin{array}{l}\text { Ojiambo et } \\
\text { al. (2012) }\end{array}$ & $\begin{array}{l}\text { determine habitual physical activity levels and } \\
\text { sedentary time } \\
\text { test for relationships between objectively } \\
\text { measured physical activity, sedentary time, and } \\
\text { adiposity }\end{array}$ & cross-sectional & 200 & $\begin{array}{l}\text { Rural (Nandi region) and urban (Eldoret } \\
\text { town) areas of Kenya }\end{array}$ & $\begin{array}{l}\text { Adolescents } \\
12-16\end{array}$ & $\mathrm{x}$ & & $\mathrm{x}$ & & & \\
\hline Tanzania & & & & & & & & & & & \\
\hline $\begin{array}{l}\text { Muhihi et } \\
\text { al. (2013) }\end{array}$ & $\begin{array}{l}\text { assess the prevalence and determinants of } \\
\text { obesity }\end{array}$ & cross-sectional & 446 & Urban: Dar es Salaam, Tanzania & $\begin{array}{l}\text { Children } \\
6-17\end{array}$ & $\mathrm{x}$ & & $\mathrm{x}$ & & & \\
\hline $\begin{array}{l}\text { Shayo and } \\
\text { Mugusi (2011) }\end{array}$ & $\begin{array}{l}\text { determine the prevalence of obesity and its } \\
\text { associated risk factors }\end{array}$ & cross-sectional & 1,249 & $\begin{array}{l}\text { Urban: Kinondoni municipality, Dar es } \\
\text { Salaam, Tanzania }\end{array}$ & $\begin{array}{l}\text { Adults } \\
18-65\end{array}$ & $\mathrm{x}$ & $\mathrm{x}$ & & $\mathrm{x}$ & & $\mathrm{x}$ \\
\hline $\begin{array}{l}\text { Mosha and } \\
\text { Fungo (2010) }\end{array}$ & $\begin{array}{l}\text { determine the prevalence of overweight and } \\
\text { obesity }\end{array}$ & cross-sectional & 222 & $\begin{array}{l}\text { Urban: Dodoma and Kinondoni } \\
\text { municipalities in TZ }\end{array}$ & $\begin{array}{l}\text { Children } \\
10-12\end{array}$ & $\mathrm{x}$ & & & & & \\
\hline $\begin{array}{l}\text { Njelekela et } \\
\text { al.(2009) }\end{array}$ & $\begin{array}{l}\text { examine the prevalence of cardiovascular } \\
\text { disease risk factors and their correlates }\end{array}$ & cross-sectional & 209 & Urban: Temeke, Dar es Salaam, Tanzania & $\begin{array}{l}\text { Adults } \\
44-66\end{array}$ & $\mathrm{x}$ & & & & & \\
\hline $\begin{array}{l}\text { Njelekela et } \\
\text { al. (2002) }\end{array}$ & $\begin{array}{l}\text { report prevalence rates of obesity and } \\
\text { dyslipidemia; examine important dietary } \\
\text { contributors to obesity and dyslipidemia }\end{array}$ & cross-sectional & 545 & $\begin{array}{l}\text { Urban: Dar es Salaam, Handeni and } \\
\text { Moduli }\end{array}$ & $\begin{array}{l}\text { Adults } \\
46-58\end{array}$ & $\mathrm{x}$ & & $\mathrm{x}$ & & & \\
\hline Uganda & & & & & & & & & & & \\
\hline $\begin{array}{l}\text { Peltzer and } \\
\text { Pengpid (2011) }\end{array}$ & $\begin{array}{l}\text { Overweight, obesity and associated factors in } \\
\text { school-going adolescents }\end{array}$ & cross-sectional & 5,613 & Uganda and Ghana & $\begin{array}{l}\text { Children } \\
13-15\end{array}$ & $\mathrm{x}$ & & & & & \\
\hline $\begin{array}{l}\text { Baalwa et } \\
\text { al. }(2010)\end{array}$ & $\begin{array}{l}\text { Prevalence of obesity and overweight in young } \\
\text { adults }\end{array}$ & cross-sectional & 683 & $\begin{array}{l}\text { rural: Kamuli } \\
\text { urban: Kampala }\end{array}$ & $\begin{array}{l}\text { Adults } \\
18-30\end{array}$ & $\mathrm{x}$ & & $\mathrm{x}$ & $\mathrm{x}$ & $\mathrm{x}$ & $\mathrm{x}$ \\
\hline $\begin{array}{l}\text { Turi et } \\
\text { al. (2013) }\end{array}$ & Geographic distribution of obesity & cross-sectional & 2420 & Uganda & 2,420 adult women & & $\mathrm{x}$ & $\mathrm{x}$ & & & $\mathrm{x}$ \\
\hline $\begin{array}{l}\text { Mayega et } \\
\text { al. (2012) }\end{array}$ & $\begin{array}{l}\text { Identification of socio-behavioral } \\
\text { characteristics associated with being } \\
\text { overweight or hypertensive }\end{array}$ & cross-sectional & 1,653 & 2 districts in Eastern Uganda & $\begin{array}{l}\text { Adults } \\
35-60\end{array}$ & $\mathrm{x}$ & & $\mathrm{x}$ & & $\mathrm{x}$ & $\mathrm{x}$ \\
\hline
\end{tabular}




\section{Discussion}

The problem of obesity is highly visible in developing countries, and especially in nowadays sub-Saharan Africa, "where socio-economic status, gender, age, parity, physical inactivity, and increased energy, fat, and sugar belong among the powerful predictors" ${ }^{\prime 18}$. Based on the meta-analysis of 16 relevant articles, this study aimed to overcome the research gap and examined the significance of different predictors of obesity in the countries of East Africa. From many different predictors mentioned in the whole research sample, only six could be analysed, one of them is a non-modifiable predictor (gender), the other five are modifiable ones. All the other five predictors are modifiable (education, type of residence, alcohol consumption, smoking and socioeconomic status) and can be influenced by behaviour and health policies.

Concerning socio-economic status the pooled results $(\mathrm{N}=8,458)$ are in line with other studies ${ }^{2,22,34}$ that also found higher socioeconomic status associated with obesity in developing countries. On the other hand, if we look at the individual studies the conclusions are not significant. In this case there were 3 studies that found an association between higher socioeconomic status and obesity and 3 that did not. This was also confirmed by Ziraba et $\mathrm{al}^{2}$, who found the opposite association. Therefore the relation of socioeconomic status and obesity is not very clear. All studies included in the meta-analysis were published between 2002 and 2013, and cover both genders. However, the pooled results are not in line with the findings of Monteiro et al. ${ }^{6}$ whose review, published a decade ago, covered studies of obesity in the developing world between 1989 and 2003. They found that obesity was also becoming a problem of poorer people in developing countries and they concluded that there was a shift towards poor people in the development of obesity, and it was associated with an increase in national GDP (Gross Domestic Product). The discordance between these results lies in the research samples. This study focused on six specific East African countries, whereas Monteiro took into consideration very different set of developing countries (e.g. Albania, India, Brazil, China, South Africa and others countries), which are economically stronger than the six East African countries. These results show that the group of developing countries is very diverse and that there are different conclusions for different income groups, as noted by Houle. ${ }^{37}$ Therefore, we emphasize that there are not enough studies to cover these problems in Africa, where there are huge differences in GDP, and especially in East Africa with countries of low HDI.

Molarius et al. $^{38}$, found an inverse association between education and obesity. This association proved to be stronger in female populations. In two included studies the educational level proved to be significant in the development of obesity, but their results showed opposite directions. When the data were pooled the significance of education disappeared. If we look closer at the individual studies ${ }^{25,29}$ and the review of Molarius et al..$^{38}$, we find some similarities. Turi et al. ${ }^{29}$ only used women in their research and concluded that higher education lowers the risk of obesity, while on the other hand, Shayo et $\mathrm{al}^{25}$ used both genders in their research and found the opposite association. This might support the idea that when researching the role of education in obesity development, gender is an important confounder.

Type of residence appears to be highly significant in presented study, people living in urban areas in East African countries are more likely to become obese than those living in rural areas. This was also found by Ziraba et $\mathrm{al}^{2,39}$. They concluded that obesity and overweight are on the rise, especially among urban populations in Sub-Saharan Africa. The same was found by Xu F., Yin X-M. and Wang $\mathrm{Y}^{40}$ in Nanjing, China. This effect is not surprising, taken into account "much lower rates of poverty and less energy expenditure that characterizes most areas in developing countries" 39 .

Concerning the prevalence of obesity in association with gender, we can conclude that women in East African countries are significantly more likely to be obese than men. This is the conclusion that can be found in the majority of studies which describe the developing world ${ }^{41}$. However, this trend is different in developed countries where there are more obese men than women ${ }^{41,42}$. This difference can be explained by different social and cultural values ${ }^{41}$. Regional differences can be found among developing countries when describing the rapidity of obesity development as cited by $\mathrm{Sahn}^{39}$, whose study reveals that in the countries of Latin America and South Asia, obesity in women develops more quickly than in the African countries. These findings confirm the conclusions about the East African countries.

In this meta-analysis the risk ratio of the pooled data did not show any results that would allow further con- 
clusions.. On the other hand, significant findings that non-smokers are more likely to become obese than smokers was found e.g. in other studies from different parts of the world ${ }^{40,43,44}$. Xu et al..$^{40}$, in study from Nanjing (China), concluded that smoking is negatively associated with BMI and that those who stop smoking are at risk of gaining weight. However, many authors are concerned about such simplistic conclusions because smoking negatively influences the health status of the population.

There was no association found between alcohol consumption and obesity in this study. Generally, studies on the association between alcohol consumption and obesity show that higher alcohol consumption and especially heavy drinking leads to obesity ${ }^{45,46}$. However, the amount of alcohol consumption was not studied in this case and therefore no conclusion can be drawn.

\section{Limitations of the meta-analysis}

The authors admit that the number of articles included in the meta-analysis is very small (for education, smoking and alcohol consumption only two studies with opposite direction of the predictors could be included) and this limits the strength of the results. However, this is also proof that the area of East Africa is not well covered by quality research studies. Therefore the region needs more academic focus as obesity is quickly becoming the problem of the future. For future studies it is important to obtain original data which was not possible in this case. Such data would allow the researchers to apply methods as correlation or regression analysis.

\section{Conclusion}

This study focused on a small region of 6 East African countries and the risk factors for obesity. The available research articles included in the meta-analysis allowed us to discuss six predictors of obesity/overweight in 3 countries from the defined region. For Rwanda, Burundi and South Sudan no appropriate articles were found. On one hand, this compromises the size of research sample and therefore the validity of the results for the whole East African region, on the other hand it clearly shows the existing research gap in this region.

Several of conclusions confirmed world trends but we also found results that are not in line with them. In the study, there were found four risk factors to be significant for obesity development - gender, type of residence, smoking and socioeconomic status. Alcohol consump- tion and education level have not proved to be significant in obesity development, which is inconsistent with general conclusions found worldwide. Women, non-smokers and people living in urban areas in East Africa are more likely to be obese. Furthermore, a higher risk of obesity was also found in people with higher socioeconomic status.

One of the conclusions is that the developing countries are a very diverse group in relation to GDP, HDI and economic growth and so it is not possible to define the same trends for all of them. In this article we have researched 6 countries in the category of "low development" and their trends are very different from those positioned higher on the HDI scale.

\section{Conflict of interest}

None declared.

\section{References}

1. Ng M, Fleming T, Robinson M, Thomson B, Graetz N, Margono C, et al. Global, regional, and national prevalence of overweight and obesity in children and adults during 1980-2013: a systematic analysis for the Global Burden of Disease Study 2013. The Lancet. 2014;384(9945):76681.

2. Ziraba AK, Fotso JC, Ochako R. Overweight and obesity in urban Africa: A problem of the rich or the poor? BMC Public Health. 2009;9(1):465.

3. World Health Organization. Obesity [Internet]. Geneva: World Health Organisation 2015 Jun [cited 2015 Jun 17]. Available from: http://www.who.int/topics/obesity/en/

4. Shirasawa T, Ochiai H, Nanri H, Nishimura R, Ohtsu T, Hoshino H, et al. Trends of Underweight and Overweight/Obesity Among Japanese Schoolchildren From 2003 to 2012, Defined by Body Mass Index and Percentage Overweight Cutoffs. J Epidemiol [Internet]. 2015 [cited 2015 Jun 16]; Available from: https://www.jstage.jst. go.jp/article/jea/advpub/0/advpub_JE20140144/_article

5. Malik VS, Willett WC, Hu FB. Global obesity: trends, risk factors and policy implications. Nat Rev Endocrinol. 2012 Nov 20;9(1):13-27.

6. Monteiro CA, Moura EC, Conde WL, Popkin BM. Socioeconomic status and obesity in adult populations of developing countries: a review. Bull World Health Organ. 2004 Dec;82(12):940-6. 
7. Yach D, Stuckler D, Brownell KD. Epidemiologic and economic consequences of the global epidemics of obesity and diabetes. Nat Med. 2006 Jan;12(1):62-6.

8. Abubakari AR, Lauder W, Agyemang C, Jones M, Kirk A, Bhopal RS. Prevalence and time trends in obesity among adult West African populations: a meta-analysis. Obes Rev. 2008 ervenec;9(4):297-311.

9. Kelly T, Yang W, Chen C-S, Reynolds K, He J. Global burden of obesity in 2005 and projections to 2030. Int J Obes. 2008 ervenec;32(9):1431-7.

10. Popkin BM, Doak CM. The Obesity Epidemic Is a Worldwide Phenomenon. Nutr Rev. 2009 Apr 27;56(4):106-14.

11. Martorell R, Kettel Khan L, Hughes ML, Grummer-Strawn LM. Overweight and obesity in preschool children from developing countries. Int J Obes Relat Metab Disord J Int Assoc Study Obes. 2000 Aug;24(8):959-67.

12. Popkin BM, Gordon-Larsen P. The nutrition transition: worldwide obesity dynamics and their determinants. Int J Obes. 2004 Nov;28:S2-9.

13. Scott A, Ejikeme CS, Clottey EN, Thomas JG. Obesity in sub-Saharan Africa: development of an ecological theoretical framework. Health Promot Int. 2013 Mar;28(1):4-16.

14. Renzaho AM. Fat, rich and beautiful: changing socio-cultural paradigms associated with obesity risk, nutritional status and refugee children from sub-Saharan Africa. Health Place. 2004 Mar;10(1):105-13.

15. Dixey R. After Nairobi: can the international community help to develop health promotion in Africa? Health Promot Int. 2014 Mar;29(1):185-94.

16. Dixey R, Njai M. The call to action: health promotion in The Gambia - closing the implementation gap? Glob Health Promot. 2013 Jun 1;20(2):5-12.

17. Stevens GA, Singh GM, Lu Y, Danaei G, Lin JK, Finucane MM, et al. National, regional, and global trends in adult overweight and obesity prevalences. Popul Health Metr. 2012;10(1):22.

18. Steyn NP, Mchiza ZJ. Obesity and the nutrition transition in Sub-Saharan Africa: Obesity and the nutrition transition. Ann N Y Acad Sci. 2014 Apr;1311(1):88-101.

19. van der Merwe M-T, Pepper MS. Obesity in South Africa. Obes Rev. 2006 Nov;7(4):315-22.

20. UNDP. Human Development Index (HDI) | Human Development Reports [Internet]. 2017 [cited 2016 May 31]. Available from: http://hdr.undp.org/en/content/human-development-index-hdi
21. Muhihi AJ, Mpembeni RNM, Njelekela MA, Anaeli A, Chillo O, Kubhoja S, et al. Prevalence and determinants of obesity among primary school children in Dar es Salaam, Tanzania. Arch Public Health Arch Belg Santé Publique. 2013;71(1):26.

22. Mosha TCE, Fungo S. Prevalence of overweight and obesity among children aged 6-12 years in Dodoma and Kinondoni municipalities, Tanzania. Tanzan J Health Res. 2010 Jan;12(1):6-16.

23. Njelekela M, Kuga S, Nara Y, Ntogwisangu J, Masesa Z, Mashalla Y, et al. Prevalence of obesity and dyslipidemia in middle-aged men and women in Tanzania, Africa: relationship with resting energy expenditure and dietary factors. J Nutr Sci Vitaminol (Tokyo). 2002 Oct;48(5):3528.

24. Njelekela, Mpembeni R, Muhihi A, Mligiliche NL, Spiegelman D, Hertzmark E, et al. Gender-related differences in the prevalence of cardiovascular disease risk factors and their correlates in urban Tanzania. BMC Cardiovasc Disord. 2009;9:30.

25. Shayo GA, Mugusi FM. Prevalence of obesity and associated risk factors among adults in Kinondoni municipal district, Dar es Salaam Tanzania. BMC Public Health. 2011;11:365.

26. Baalwa J, Byarugaba BB, Kabagambe EK, Kabagambe KE, Otim AM. Prevalence of overweight and obesity in young adults in Uganda. Afr Health Sci. 2010 Dec;10(4):367-73.

27. Mayega RW, Makumbi F, Rutebemberwa E, Peterson S, Östenson C-G, Tomson G, et al. Modifiable socio-behavioural factors associated with overweight and hypertension among persons aged 35 to 60 years in eastern Uganda. PloS One. 2012;7(10):e47632.

28. Peltzer K, Pengpid S. Overweight and obesity and associated factors among school-aged adolescents in Ghana and Uganda. Int J Environ Res Public Health. 2011 Oct;8(10):3859-70.

29. Turi KN, Christoph MJ, Grigsby-Toussaint DS. Spatial distribution of underweight, overweight and obesity among women and children: results from the 2011 Uganda Demographic and Health Survey. Int J Environ Res Public Health. 2013 Oct;10(10):4967-81.

30. Christensen DL, Eis J, Hansen AW, Larsson MW, Mwaniki DL, Kilonzo B, et al. Obesity and regional fat distribution in Kenyan populations: Impact of ethnicity and urbanization. Ann Hum Biol. 2008 Apr 3;35(2):23249. 
31. Gewa CA. Childhood overweight and obesity among Kenyan pre-school children: association with maternal and early child nutritional factors. Public Health Nutr. 2010; 32. Jayne J, Scrimgeour A g., Polhemus M e., Otieno L, Bovill M e. Dietary and Socio-Economic Correlates of Nutritional Status in a Rural Adult Kenyan Population. Afr J Food Agric Nutr Dev. 2011 ervenec;11(4):5035-52.

33. Kamau JW, Wanderi MP, Njororai WWS, Wamukoya EK. Prevalence of overweight and obesity among primary school children in Nairobi province, Kenya. Afr J Phys Health Educ Recreat Dance. 2011 erven;17(2):312-27.

34. Steyn NP, Nel JH, Parker W-A, Ayah R, Mbithe D. Dietary, social, and environmental determinants of obesity in Kenyan women. Scand J Public Health. 2011 nor;39(1):88-97.

35. Ojiambo RM, Easton C, Casajús JA, Konstabel K, Reilly JJ, Pitsiladis Y. Effect of urbanization on objectively measured physical activity levels, sedentary time, and indices of adiposity in Kenyan adolescents. J Phys Act Health. 2012 Jan;9(1):115-23.

36. Kyallo F, Makokha A, Mwangi AM. Overweight and obesity among public and private primary school children in Nairobi, Kenya. Health (N Y). 2013;05(08):85-90.

37. Houle D. How Obesity Relates to Socioeconomic Status [Internet]. Population Reference Bureau. 2013 [cited 2016 May 31]. Available from: http://www.prb.org/ Publications/Articles/2013/obesity-socioeconomic-status.aspx

38. Molarius A, Seidell JC, Sans S, Tuomilehto J, Kuulasmaa K. Educational Level, Relative Body Weight, and Changes in Their Association Over 10 Years: An Inter- national Perspective From the WHO MONICA Project. Am J Public Health. 2000 Aug;90(8):1260-8.

39. Sahn DE. Weights on the rise: where and for whom? J Econ Inequal. 2009 Dec;7(4):351-70.

40. Xu F, Yin X-M, Wang Y. The association between amount of cigarettes smoked and overweight, central obesity among Chinese adults in Nanjing, China. Asia Pac J Clin Nutr. 2007;16(2):240-7.

41. Bhurosy T, Jeewon R. Overweight and Obesity Epidemic in Developing Countries: A Problem with Diet, Physical Activity, or Socioeconomic Status? Sci World J. 2014;2014:1-7 PubMed .

42. Kanter R, Caballero B. Global Gender Disparities in Obesity: A Review. Adv Nutr Int Rev J. 2012 Jul 1;3(4):4918.

43. Dare S, Mackay DF, Pell JP. Relationship between smoking and obesity: a cross-sectional study of 499,504 middle-aged adults in the UK general population. PloS One. 2015;10(4):e0123579.

44. Flegal KM, Troiano RP, Pamuk ER, Kuczmarski RJ, Campbell SM. The influence of smoking cessation on the prevalence of overweight in the United States. $N$ Engl J Med. 1995 Nov 2;333(18):1165-70.

45. Brumby S, Kennedy A, Chandrasekara A. Alcohol consumption, obesity, and psychological distress in farming communities-an Australian study. J Rural Health Off J Am Rural Health Assoc Natl Rural Health Care Assoc. 2013 Jun;29(3):311-9.

46. Shelton NJ, Knott CS. Association between alcohol calorie intake and overweight and obesity in English adults. Am J Public Health. 2014 Apr;104(4):629-31. 